\title{
\$100m payout after drug data withheld
}

[WASHINGTON] A pharmaceutical company has agreed to pay nearly $\$ 100$ million to settle potential legal claims from an estimated five million patients who have taken the anti-hypothyroidism drug Synthroid.

Knoll Pharmaceutical of Mount Olive, New Jersey, a subsidiary of the giant German group BASF, was charged with costing the patients more than $\$ 2$ billion because it suppressed research findings that showed Synthroid was no more effective than cheaper competitors.

Knoll announced earlier this month that it would pay at least $\$ 98$ million to plaintiffs rather than fight the charges in court. This appears to be the first time that patients have won compensation based on a sponsor's treatment of the results of a research trial.

More than a dozen class-action lawsuits have been filed against Knoll, alleging violation of state consumer protection and fraud statutes, as well as federal anti-trust and racketeering laws.

Knoll is accused of suppressing publication of a study that showed that one brandname and two generic competitors were as effective as the more costly Synthroid. The study concluded that health-care costs could be cut by $\$ 356$ million a year if cheaper equivalents were used instead of Synthroid.

The British company Boots, which owned Synthroid before Boots' drug division was taken over by BASF in 1995, had threatened to sue Betty Dong, a clinical pharmacist at the University of California, San Francisco (UCSF), who led the study, because she had signed an agreement not to publish results without its consent.

The threat came just before an article by Dong went to press in the Journal of the American Medical Association (JAMA) in 1995, and Dong withdrew her paper after officials at UCSF refused to back her and her colleagues.

Before lawyers' fees are deducted, this month's settlement would provide about $\$ 19.60$ to each of five million people eligible for damages. The company says it will pay up to $\$ 135$ million if more than five million plaintiffs come forward.

Knoll insists that the settlement "in no way implies or acknowledges any wrongdoing". Knoll's president Carter Eckert says it was agreed "to avoid burdensome and expensive litigation".

Consumer activists complain that the settlement is too small. Paying each patient less than $\$ 20$ is "absolutely an outrage", says Sidney Wolfe of the Public Citizen Health Research Group.

Drummond Rennie, a deputy editor of JAMA and a professor of medicine at UCSF, agrees. He calculates that Knoll will pay out less than 5 per cent of an estimated profit of
$\$ 2.1$ billion that it made by suppressing the findings between 1992 and 1997. "I'd feel pretty cheery if I were the company," wrote Rennie in an editorial accompanying the Dong paper's eventual publication in April.

But Barry Himmelstein, a lawyer for the plaintiffs at the San Francisco firm of Lieff, Cabraser, Heimann, and Bernstein calls the settlement "unusually good", and says he expects plaintiffs to recover "a substantial portion of their potential losses".

Some bioethicists say that the agreement sets an important precedent. Arthur Caplan, director of the Center for Bioethics at the University of Pennsylvania, says it is the first time in the history of US science that a group of patients has filed a class-action suit alleging injury because of the way in which research findings have been handled. "It shows that patient groups can get redress when they feel they have been mistreated in the context of a research trial."

The case does not, however, set a precedent in a strictly legal sense, as it was resolved out of court. And experts point out that, had it gone to trial, Knoll would have had a legal defence because of Dong's written agreement with the company.

Some observers feel that the company settled to avoid protracted bad publicity. But they say that the settlement is still likely to send a warning to the pharmaceutical indus-

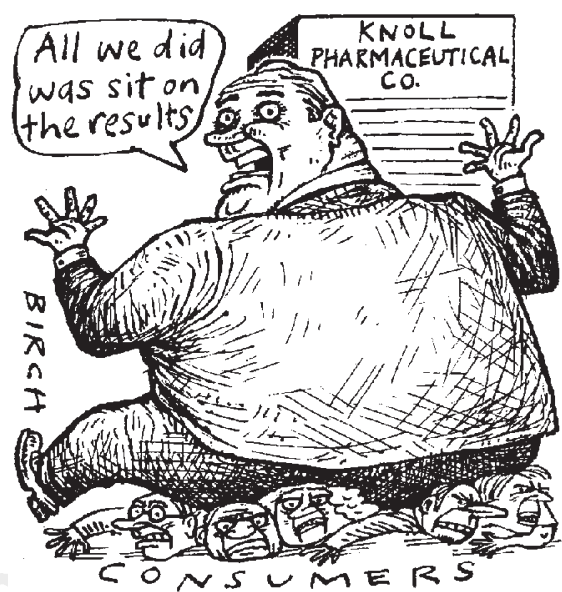

try. Wendy Mariner, professor of health law at Boston University, says that companies could choose to avoid vulnerability to similar lawsuits "by saying that anyone can publish anything he or she wants".

Bioethicists and lawyers also stress that the episode should warn researchers against signing agreements with industry that cede rights to publish. They say that the behaviour of officials at UCSF in refusing to put legal resources behind Dong should be an object lesson. "It makes the researchers look expendable. That's a danger if you wish to have credible research emerge from universities," says Mariner.

MeredithWadman

\section{'Action needed to counter bioterrorism'}

[WASHINGTON] The United States is failing to employ the power of its biotechnology and pharmaceutical industries to counter a growing threat from biological terrorism, an expert conference was told last week.

Biological terrorism is becoming more likely as both information and biological agents become more available, said David Siegrist, a research fellow at the Potomac Institute for Policy Studies, which hosted the conference in Washington, DC.

"There is a crying need for much more to be done," said Siegrist, who leads a research team studying how to counter biological terrorism. "The US advantage in biotechnology needs to be leveraged, so that it outpaces the threats."

The United States is not as well prepared to counter the threat as it should be, according to Siegrist's research. A 1996 report from the Federal Bureau of Investigation concludes that, although terrorist incidents in the United States are decreasing in number, they are increasing in destructive power and casualties inflicted. "Over the past ten years a pattern of interest in biological agents by criminals and extremists has developed," says the report.
Siegrist's team argues that increased funding for biomedical research into advanced countermeasures is needed. The lack of incentives for industry to invest means that government must do more.

A recent official review of US defence policy concluded that protecting Americans from weapons of mass destruction is a top priority, yet recommended that just \$1 billion over five years be put into developing tools to counter the impact of domestic attacks by such weapons.

But Stephen Morse, the manager of a new advanced diagnostics programme for pathogens at the US Defense Advanced Research Projects Agency, points out that the agency has boosted its funding for countering biological threats to $\$ 50-\$ 60$ million in the past few years. This is a "significant commitment", he says.

Technologies being developed by the government include biosensors - tiny devices that can identify biological agents in the body or in the environment. Advocates of increased research point out that there are many potential applications in the civilian sector, from food safety inspections to countering infectious diseases. 